University of Nebraska - Lincoln

DigitalCommons@University of Nebraska - Lincoln

To Improve the Academy

Professional and Organizational Development Network in Higher Education

1994

\title{
A Report Card for Diversity
}

Johnnella E. Butler

Follow this and additional works at: https://digitalcommons.unl.edu/podimproveacad

Part of the Higher Education Administration Commons

Butler, Johnnella E., "A Report Card for Diversity" (1994). To Improve the Academy. 303.

https://digitalcommons.unl.edu/podimproveacad/303

This Article is brought to you for free and open access by the Professional and Organizational Development Network in Higher Education at DigitalCommons@University of Nebraska - Lincoln. It has been accepted for inclusion in To Improve the Academy by an authorized administrator of DigitalCommons@University of Nebraska - Lincoln. 


\section{A Report Card for Diversity}

\section{Johnnella E. Butler}

University of Washington

This article was originally prepared for and presented as the keynote address for the 1993 POD conference. As an assessment of where we are and need to go intellectually in efforts to incorporate diversity into the liberal arts curriculum, it argues for the recognition of the multiple, connected stories in our national story, in order to allow for a transformation in our teaching, our curricula, and in the structure of colleges and universities that moves us to an individualism defined and supported by collective, shared memory, thereby promoting the generative learning necessary to the evolution of a just, plural society.

I have been a little concerned the past few years with how diversity in higher education runs the risk of becoming meaningless. By this, I mean it frequently becomes something through which we look at all experiences equally, tending to forget the quest for knowledge that is at the center. We seem to have lost a sense of our U.S. American context, a context that carries its perspective even as we attempt to address diversity globally. I want to share my ideas with you as to how we can place or position the work, the various work that we do in higher education that is concerned with diversity, in a context that will inform our strategies, inform our processes, inform the way we restructure the institution, inform the way we teach our classes.

In the early years of this century, Langston Hughes wrote a poem reminding us of the scope and depth of the Negro past. Like many African American, Asian American, American Indian, and Chicano/ Latino cultural expressions, it is taught, when it is taught, only as 
specific to and particular to its racial/ethnic experience. Somehow, it is very difficult, if it happens at all, for a cultural expression, an historical event of U.S. people of color to be seen as both particular to their experience and to a larger collective U.S. American experience. Some of you may know the poem:

Ive known rivers:

I've known rivers ancient as the world and older than the flow of human blood in human veins. My soul has grown deep like the rivers.

I bathed in the Euphrates when dawns were young.

I built my hut near the Congo and it lulled me to sleep.

I looked upon the Nile and raised the pyramids above it.

I heard the singing of the Mississippi when Abe

Lincoln went down to New Orleans, and I've seen it's muddy bosom turn all golden in the sunset.

I've known rivers:

Ancient dusky rivers.

My soul has grown deep like the rivers.

How can that poem become our poem? How, for example, can the history of Japanese Americans placed into internment camps become our story? How can the caring and work it takes to help the thirteen year-old gang member who pleaded with my colleague in an interview in D.C., "Please don't forget us?" - how can the caring, sacrifice, and dedicated work it will take to help him, and others like him - be our responsibility? How can the taxes we need to pay to give healthcare to the poor, malnourished children in Appalachia, or just down the street from us, be our responsibility?

Curriculum transformation, a term that has evolved from our efforts over the years to incorporate white women, women of color, men of color into the largely white male curriculum in higher education, represents a strategic, heartfelt effort towards the goal of U.S. citizens knowing that they have one big story composed of many 
stories: some not quite as big, almost as big, small, and some very small. Fourteen years ago, I completed my dissertation which later became a book, Black Studies: Pedagogy and Revolution, widely read in Black Studies circles and used in graduate seminars on pedagogy and literature for the five years it remained in print. This study examines the conceptualizations of American and African American identity in African American literature, as well as the ways African American literary and cultural expression challenges the resulting dichotomies. These challenges, and African American alternatives to them, formed the foundation of the pedagogy I described, based in Freirian liberation pedagogy in an American context. What I envisioned then, what I called "revolution," is what I more aptly and precisely named "transformation" in my more recent work.

This transformation - begun with the 1960s push by AfricanAmericans for access to desegregated higher education - and then for Black Studies, began today's movement to address what we call "diversity in higher education." As a college student in the 1960s, I knew that a great deal was missing from my education. I intuited that once the missing information and ideas were raised and addressed, the very fabric, if you will, the shape, the texture, the content of the liberal arts would have to change. I wondered, for example, about the South American writers of African descent and the Afro-Latino folktales and cultural ways that were missing in my study of what was then called "Spanish American Literature." I knew that if those silenced writers were read in our courses and if the African influence in the folkculture of Latin American literature were examined, the courses in my minor would have to change significantly. Likewise, I knew that if we had studied not only Othello in my Shakespeare course, but also the Moors' occupation of Spain, that Othello would not remain the oddity, the aberration that he appeared to be. In other words, courses would be transformed. Our approach to knowledge and information would be transformed. We would seek out the connections and interconnections in history, cultural expression, the sciences, the social sciences. We would not shy from what appeared different and would not only embrace and feel comfortable with what seemed similar to what we already knew. We would begin to understand that there are unities and diversities; that synthesis, while it may be desirable, is not always 
immediately possible; and that, therefore, we may have to - and may even want to - live frequently with the tensions of contradictions, growing through the ideas of situations those tensions generate. And this is what I meant, then, by "revolution" and now by "transformation."

We have many terms to define and describe our attempts to reckon with the diversity of this nation. We want to incorporate diversity into higher education. We want to advance multiculturalism as an approach to teaching. Ten years ago in Women's Studies we wanted to balance the curriculum in reference to gender, to advance curriculum integration in reference to gender. Around the same time we wanted to mainstream women into the curriculum. We can trace the beginnings of advocacy of pluralism in American higher education to the early years of this century; yet, the most immediate beginning of what some call today's multicultural movement was initiated by legal cases begun by black Americans in the 1920 s seeking the right to education. Those long, hard battles fought over the years by Charles Houston, Constance Baker-Motley, Justice Thurgood Marshall, attorney Jack Greenberg, among others, culminated in the sixties in access to higher education for Black Americans. The law was quickly extended to women and other minorities, as the term was then.

Black students on overwhelmingly white campuses demanded Black Studies. They wanted to know their history, an ignored history, the exclusion of which left big unanswered questions and huge gaps in what we called "American History." That demand was quickly imitated and emulated. White women demanded Women's Studies; Puerto Ricans, Puerto Rican Studies; Asian Americans, Asian American Studies, and so forth. Those demands to develop scholarship further and to address experience in scholarship should be viewed as very important, even central, to our efforts today to address diversity in higher education. The resulting fields of study are central to curriculum and institutional transformation. If, indeed, we are serious about meeting the needs of our rapidly changing student population in order that they may have productive lives, hold jobs in a reasonably safe, vibrant society, then we must keep the vision of one big, shared U.S. story that has multiple complementary and conflictive stories as we seek to define relationships between Student Affairs and Academic 
Affairs, as we seek to help TAs teach composition classes and help faculty improve their classroom climate.

I will outline the contour and context of that big story. Then, I will offer a few suggestions to you. My remarks reflect the definition of curriculum transformation that is, in its broadest sense, the rethinking and recasting of what and how we teach in order to reveal the unity and diversity, the connections and interconnections among that which seems different, in order to comprehend the complexity of the human condition. As Paolo Freire has shown, literacy implies more than the ability to read and count. As the history of American slavery reminds us, learning to read and count were closely connected to the slaves perceiving fully their human condition and the Christian misuse of the Bible to justify slavery. Learning to read and count, we see, led, if not directly to revolt, to an intense desire for freedom. Literacy, then, is inextricably joined with the freedom that is dependent on our knowing one another, becoming conversant with one another, and building on the best of our traditions in the approximation, if not the achievement, of wholeness. We need, then, a sense of a collective story in order to begin to find the balance between our physical and our spiritual selves - the balance between the material world and whatever it is, in the many ways we identify it, that is more than our spiritual selves, than our physical selves.

Constantly negotiating for balance between and among opposites is necessary to the ever-evolving, changing context to our collective big story. For example, in my graduate course, American Ethnic Literary Criticism, we struggle with the the multiple literatures in the United States. Those multiple literatures have different and similar standards and aesthetics. So how do we converse, how do we talk about an American aesthetic that is multiple-centered, that is dynamic, that is changing? There is a way to do it, by engaging the complexities of racial, ethnic identities, gender identities, class, sexual identities, as they shape the aesthetic expressions and critical evaluations of those expressions. This must become a part of our literary analyses. We have to engage difference. We have to engage contradiction. We need to carry with us as we try to teach students, prepare syllabi, as we determine process, that we are all part of a huge, deeply flawed, 
experiment which we must make work for the good of all and not just a few.

From the founding of this nation to the present day, the United States has been described as The Great Experiment. The Experiment would demonstrate whether or not Europeans of diverse backgrounds could establish a nation characterized by religious and ethnic tolerance. These Europeans were essentially Northern Europeans, mostly of English and Dutch descent. With the arrival of Europeans from Ireland, Italy, and Poland in the mid and late nineteenth century, The Experiment was severely taxed. While free Negro and White abolitionists had protested the enslavement of Black people and the severe racism and discrimination against free Negroes since the seventeenth century, the severe test of this experiment brought about by the arrival of those Europeans coincided with the push toward the emancipation of the enslaved people of African ancestry and the removal of the American Indians from choice territory.

In order for The Experiment not to fail, an experiment limited to White people mind you, certain accommodations were made on the basis of race. Very soon, for example, by the early nineteen hundreds, signs such as "No Irish or Dogs Need Apply" disappeared from windows in cities like Boston. And it was not very long before those same Irish people and their descendants, because of the special entry given to them on the basis of race, had infiltrated the political systems in Boston, New York, and Chicago, among other cities, and turned the politics and economies of those cities around to their own, very positive, advantage. Such personages as the Kennedys and the Fitzgeralds of Boston, the late Richard Daley and his son of Chicago, New York's dapper Jimmy Walker, mayor and songwriter, and New York mayor, Bill O'Dwyer, became prominent products of this modification of The Experiment. George Olvany, Chief of Tammany Hall in New York City, boasted in 1932, "The Irish are natural leaders. The strain of limerick keeps them at the top. Even the Jewish districts have Irish leaders. The Jews want to be ruled by them (Walter, p. 50)." In similar fashion, but at a later date, the construction of The Experiment was modified to incorporate the waves of Italian immigrants in the late 1800 s and early 1900 s. They followed the lead of the Irish. The best known is Carmine DeSapio, who led the Italians to power in New York 
after World War II, becoming Chief of Tammany Hall in the early 1950s.

No such accommodations or modifications of The Great American Experiment were made for the Asian immigrants, Chinese and Japanese, who began to arrive in significant numbers after the American Civil War. Although they made great contributions in the building of the great Transcontinental Railroad and the development of California, Oregon, and Washington, evidences of their exclusion from The American Experiment are the several agreements and acts severely limiting their immigration. The most stark evidence of their domestic exclusion, of course, is the World War II internment of Japanese Americans.

In the same way that there was no modification of The Experiment for Asian Americans, there was none for Mexican Americans. Common characterizations for the Mexican Americans, said with impunity in the first half of this century, were "Wetbacks," "Greasers," and "Desert Dagos." Their exclusion from The Experiment relegated them to the margins of The American Experiment and confined most to a condition of extended peonage.

For the American Indian, who suffered massacres, the loss of land, rights, and practically all sources of wealth and well-being, The Great Experiment was irrelevant. The same can easily be said for people of African ancestry in the United States who went from slavery to peonage to, what appears to some still to be, permanent second-class citizenship. This Experiment, intended to establish "a city on the hill" (Ronald Reagan used to say "a shining city on the hill"), a Western Zion, a Western Garden of Eden, was from the beginning severely flawed, despite its stated goal of inclusiveness and human idealism. It denied, on the basis of a construction of race and racism, the inclusion of men and women of color, those who were here when the Spanish and the English arrived, those whom they brought for enslavement, and those whom they brought for peonage. Clear evidence of this dysfunction is evidenced in the American Constitution when it condoned slavery by allowing it to continue, not mentioning it by name.

Acknowledging the moral contradiction of a democracy built on the enslavement of African peoples and on the near annihilation of the American-Indian; recognizing the connection of that moral contradic- 
tion to the development of institutional racism; and understanding the dependent relationship between white privilege and racism, are the lessons of the contour, the context, if you will, of our stories - of all our stories. The stories that need to be told, that are being told, are many and myriad. They are male stories, female stories, they are gay and lesbian stories, ethnic stories, racial stories, class stories, stories of differing physical abilities. And our biggest task, I think, is to figure out just what all these stories mean to our work, to our lives, to our conceptualizations of just what this nation is.

At a conference last fall of project directors and participants of eighty campuses that have been funded by The Ford Foundation, an observation I have made through my travels over the past two years was unfortunately confirmed. I mentioned at the beginning of my presentation, that we have become more focused on how to be inclusive, to the exclusion of the why, of what, must change. Participants presented many workshops, mostly focused on how to encourage diversity; how to structure faculty development workshops and seminars; how to recruit faculty of color; how to involve student leadership and diversity initiatives. We were all very much concerned and focused on the how to. Few of us had considered the what of encouraging diversity of curriculum transformation. We told stories at that conference, yet we shared little, if any, collective consciousness. We did not know what to do with those stories, just as we frequently do not know what to do with our diversities, once we find ways to acknowledge them. Their what, their significance, was not easily, readily available and applicable to the how. Many approached addressing diversity on our campuses with the celebratory model, "We're all so different and that's good," and, hence, found it hard to build on commonalities they sensed were there yet had not sought as they sought the differences. They found that their efforts further alienated students one from the other. Others busily strategized for more financial support of faculty development for the hiring of minority faculty, but despaired at the resistances of some faculty and the inability to retain minority faculty in their campus environment.

It turned out to be a successful conference, ultimately, because through two difficult plenary sessions, we came to understand at least three important points: 
1. We cannot ignore, avoid, or otherwise diminish the important role of racism (personal or institutional) in defeating our attempts to provide an inclusive, generative curriculum in campus environment. Trying to understand racism does not increase the differences, but rather illuminates the similarities, the commonalities.

2. If we do not recognize and analyze the permeation of racism throughout our campuses, then our efforts for diversity will fail. The physically challenged may be present, provided for, and included, but they may still be subjected to racism or enjoy white skin privilege, depending upon who they are. Gays and lesbians may be rid of experiencing homophobia, but Chicana lesbians and Asian American gays, for example, may still be discriminated against on the basis of color.

3. We should not just add on an American Indian novel or a discussion of the Asian American family to a syllabus, but rather consider the American Indian novel as a part of a multiple-voiced American literature, and Asian-American family structures as a multiple and as part of complex American family structure.

In other words, we learned that we had to begin to hear our multiple stories and grapple with the content in our stories, even when that content made us most uncomfortable.

Let me give you two examples and conclude with my sense of what all of this means. Some years ago the movie "The Big Chill" came out. When I saw it, I was struck by how it was presented as the story of the sixties, the sexual revolution, the divisiveness of the Vietnam War, the rebellion against authority. For me, and many like me, the sixties meant living through desegregation and its ambiguities. It meant finding the strength and courage to be the first black in my school, the only black in my class, of being directed to eat in the kitchen at a truck stop on my way with my family to my cousin's wedding when our car broke down in the middle of the passage of Voting Rights and Accommodation Acts. It meant not rebelling against authority, but, rather, expecting the law and authority to bring about the justice it promised. My point is not that the Civil Rights and Black Power story of the sixties is more important, but rather, one should not be told without at least the presence, the context, of the other, for they are all very closely intertwined at points. Perhaps this is obvious to me, 
who had an Irish-American boyfriend who protested the War, rebelled against the Church and his parents, and who found himself punching out his friends when they disrespected me, by calling me, "Johnny's little colored girlfriend." It may be that the connections are obvious to me because of such experiences.

I'm going to refer to a story told at the diversity conference in Seattle last fall, to which I referred earlier. An administrator told it, a Chinese American administrator, and I'll truncate it. He said he told this story at a meeting of administrators in response to someone else trying to explain how they felt uncomfortable on their campus; how they encountered racism on their campus. Growing up in the midwest, he was doing very well in school - was very successful. It came time for the senior prom. He selected someone to ask to the prom. He asked a young girl to the prom, and her parents wouldn't let her go with him because he was Chinese American. Now, the response to his story by the administrators who were discussing diversity was particularly telling. One white administrator stood up and he said, "Well, you know, I know most of the administrators here and most of us didn't have dates to our prom. It's really a problem for administrators to get dates to their prom." Everyone laughed, nodding in agreement. The Chinese American administrator, who had told his story of pain and rejection, was mortified. He said at that moment he understood, even more, the depth of the meaning in other stories that people of color had told at this gathering as an effort to address racism.

We level stories. We level experiences so that the specificity is lost and diminished. However, only by engaging that specificity will we transform ourselves and society. We must seek to understand a story in the context of a shared collective consciousness, name what has happened, and seize the transformative moment of understanding that experience, the pain and the joy of that experience. Thus, we will not move so quickly to be comfortable, to impose a sameness, to ease our discomfort.

So what does all of this mean? I can only begin to say what it means. It means something special to each and everyone of us at a personal level. It means something at an institutional level. It means something in the classroom. It does mean we must engage in an understanding of our history that will provide a context for the work 
we do, in my case, a context for the work of curriculum change, the context of incorporating diversity into the curriculum, into our pedagogy. Or else, we will simply give voice to a few of those excluded and that voice will be quickly distorted. It means that curriculum transformation must permeate the institution and the entire curriculum. It is not a topic to be studied apart from everything else.

Second, it means that the subject content of Ethnic Studies, African American Studies, American Indian Studies, Asian American Studies, Chicano/Latino Studies, and Women-Studies must be taken seriously as fields of studies with programs and/or departments to generate scholarship in those areas in addition to being simultaneously incorporated into the other disciplines.

Third, in traditional courses, the story of assimilation of the Euro-American must be told. The American Jew story must be told, complete with the meaning of anti-semitism and the paradoxical nature of their U.S. experience: being victims of bigotry and discrimination on the one hand, and enjoying the privileges of white skin on the other. Everyone's story can't be told, as we know, in trying to represent diversity in the classroom. Time and space don't allow. But the contours of our collective story can be told, studied, so that the recent Arab American immigrant or Eastern European American immigrant can understand how he or she is experiencing this nation, how he or she is experiencing our institutions and not repeat experiencing the offenses that stem from our keeping ourselves and our stories isolated.

Fourth, it means that race, class, gender, and ethnicity, as four basic and shared components of our human identities, should serve as organizing principles and categories of analysis for curriculum transformation. It means establishing structure to incorporate diversity. Race, class, gender, ethnicity, and other differences function in a matrix-like manner. They are interconnected, shape one another. As we foreground gender, for example, race, class, and ethnicity are connected with gender, alter and affect it. We must find ways in our scholarship, in organizing our campuses to allow for this interconnectedness to be seen. The most accessible example for understanding how we might begin to think, to incorporate this interconnectedness in many other ways in our scholarship, in our daily lives is through, 
perhaps, the metaphor of the jazz ensemble. If you think of a jazz ensemble, say a piano, a saxophone, a trumpet, and a bass they all play together and, periodically, one of the musicians will step forward and improvise. We call that a solo. But think about it. It is not a solo at all in the true sense of the word. While what the musician plays is very distinguishable from the ensemble's earlier music, it is connected, intertwined, with what came before and with what is supporting him or her during the solo. The solo anticipates what follows when the solo musician steps back into the group. The improvising musician is always aware of what the group is doing. He or she bounces themes, variations, off the group. They interact with and shape one another, even while one is foregrounded. So, too, gender interacts with race, class, and ethnicity. The same holds true when foregrounding race, class, or ethnicity. And the same holds true for our stories. As one story is foregrounded, it is connected with the stories of others we don't even know. It is connected with that big collective consciousness.

Fifth, we must reconceptualize Western Civilization in the context of other stories that interconnect with its story. Historically, and traditionally we have treated Western Civilization as a perfect entity, not affected by other civilizations. In fact, we have denigrated other civilizations claiming their inferiority to ours. We must explain the relationships among imperialism and colonialism, colonization and racism. Our students must know the "whys" of the genocide of American Indians, African peoples, indigenous Australian peoples, of the holocausts of Southeast Asia, as well as the better known recent holocaust in Germany. We must present our students with the beautiful and the ugly. They must understand the complexities of Western and American Civilization. They must respect and be familiar with multiple points of view. So far, the students have the story of the elite well told. Yet, they must understand that of the disenfranchised, the dispossessed of this nation of sheep, or they won't be able to recognize the dangers emanating from their own ignorance. In some ways, we are close to that tragedy right now.

And sixth, the incorporation of diversity must have as its goal the transformation of our curriculum. The academic areas that can guide us and interact with the traditional disciplines are Ethnic Studies and 
Women Studies, and pedagogical and scholarly methodologies that include racial, class, gender, and ethnic analyses across the curriculum. Transformation requires an affirmation and a reckoning with the connections among disciplines, of living in the boundaries, of living within the blurred boarders, and a radical shift in our cultural perception from the legacy of rugged individualism to the communality reflected in the jazz metaphor. Some of you who have read my work, know that I like to express that through the West African proverb "I am we," which is gramatically incorrect in English, but which says what we need to be thinking. Structurally, it implies the need for faculty development, team teaching, comparative study, interdisciplinary programs, and interdisciplinary departments.

What I have tried to do is provide you with some initial thinking about the context for addressing growing diverse populations in higher education, in order to encourage a transformation that allows for a supportive, meaningful environment for all our students: Black, White, Yellow, Red, immigrants, gay, lesbian, older, younger, the physically disabled, whomever. Somehow, we have got to find a way for our institutions to create the space and time for our souls to grow deep like the river - for Leslie Silko, Langston Hughes, Amy Tan, Toni Morrison, Sandra Cisneros, Frank Chin, as well as Nathaniel Hawthorne and Margaret Atwood to belong to all of us, because we can own their stories. Then we will not have courses on The Family, but rather on Families. We will not have theories of deviance based on racist norms. And we will naturally encourage women chemistry students from all backgrounds as well as we unthinkingly encourage White male chemistry students.

Our souls will grow deep together.

\section{References}

Butler, J. E. (1981). Black studies: Pedagogy and revolution: A study of Afro-American studies and the liberal arts tradition through the discipline of Afro-American literature. Washington, D.C.: University Press of America.

Butler, J. E. and Walter, J. C. (Eds.). (1991). Transforming the curriculum: Ethnic studies and women's studies. Albany: State University of New York Press.

Freire, P. (1969). Pedagogy of the oppressed. New York: Seabury. 
Walter, J. C. (1989). The Harlem Fox: J. Raymond Jones and Tammany, 1920-1970. New York: State University of New York Press. 